\title{
Leptospira hebdomadis associated with an outbreak of illness in workers on a farm in North Yorkshire
}

\author{
S M CRAWFORD AND D W MILES \\ From Airedale General Hospital, Steeton, Keighley BD20 6TD, UK
}

ABSTRACT Four cases of illness attributed to Leptospira hebdomadis occurred on a cattle farm in North Yorkshire. The clinical features were a febrile illness that resembled influenza; in one case there was a lymphocytic meningitis. This infection is probably more common than is recognised at present, and prevention of further cases may be possible if diagnosed promptly.

The Leptospira hebdomadis serogroup was responsible for 33 out of 65 cases of human leptospirosis confirmed serologically by the Leptospira Reference Laboratory in $1978 . .^{1}$ Most of the patients were farmers or farmworkers who were in contact with cattle, and these were largely isolated cases.

We report the occurrence of leptospirosis in several workers on a farm in North Yorkshire; serological tests showed that they had agglutinating antibodies to the hebdomadis serogroup. The outbreak has provided an opportunity to observe the spectrum of clinical features associated with this infection. All the individuals worked with cattle; employees who worked with sheep were not affected.

\section{Case reports and investigations}

Case 1-A 34-year-old farmer consulted his general practitioner in late September 1978 with a three-day history of dysuria, feverishness, and rigors. $\mathrm{He}$ was treated empirically for a urinary tract infection with co-trimoxazole and his symptoms subsided, but five days later he complained of headache. Neck stiffness was found on examination. On admission to hospital that day he was apyrexial. The cerebrospinal fluid showed a lymphocytosis with no other abnormality. Culture for viruses was negative. He made an uneventful recovery over the next three days and had a prolonged convalescence at home. Serology for brucella was negative, and at the time viral meningitis was diagnosed.

Case 2-This 38-year-old cowman had started

Requests for reprints to: Dr S M Crawford, Department of Haematology, Bradford Royal Infirmary, Duckworth Lane, Bradford BD9 6RJ.

Received 12 September 1979

Accepted 13 December 1979 work on the farm in November, two weeks before he became ill. He had an influenza-like illness that lasted a week and then subsided. He then became acutely ill with headache and photophobia and was admitted to hospital. Neck stiffness was absent. Cerebrospinal fluid was entirely normal.

Both patients remarked that there had been several cases of similar illness in workers on the farm. Case 1 was therefore screened as an outpatient for leptospirosis and listeriosis. The initial agglutination titre to $L$ hebdomadis was 1:3000 (Leptospira Reference Laboratory). The other affected workers and other people associated with the farm who had had febrile illnesses were therefore screened. The results are listed in the table.

Results of screening for L hebdomadis agglutination titre

\begin{tabular}{|c|c|c|c|}
\hline Case No & Nature of illness & $\begin{array}{l}\text { Association with } \\
\text { farm }\end{array}$ & $\begin{array}{l}L \text { hebdomadis } \\
\text { agglutination } \\
\text { titre }\end{array}$ \\
\hline 1 & \multirow{6}{*}{$\begin{array}{l}\text { Lymphocytic } \\
\text { meningitis, dysuria } \\
\text { "Flu-like"'illness, } \\
\text { meningitis } \\
\text { "Flu-like" illness, } \\
\text { prolonged } \\
\text { convalescence } \\
\text { Bad headaches, } \\
\text { dysuria, fever } \\
\text { Tonsilitis } \\
\text { "Flu-like" illness }\end{array}$} & Farmer & $1: 3000$ \\
\hline 2 & & New cowman & $1: 3000$ \\
\hline 3 & & Head cowman & $1: 100$ \\
\hline 4 & & & \\
\hline 5 & & $\begin{array}{l}\text { Assistant cowman } \\
\text { Schoolboy son of } \\
\text { case } 3\end{array}$ & $\begin{array}{l}1: 300 \\
\text { Negative }\end{array}$ \\
\hline 6 & & $\begin{array}{l}\text { Son of neighbouring } \\
\text { farmer. } \\
\text { Occasional visits to } \\
\text { affected farm }\end{array}$ & Negative \\
\hline
\end{tabular}

Sixteen of the cattle concerned have also been investigated. Twelve had complement-fixation titres of between $1: 100$ and $1: 1600$ to $L$ hebdomadis. They had been bought from a neighbour in the month in which the outbreak started. There was no evidence of 
leptospiral infection in the serum of the previous owner of these cattle. Since he dealt with the cattle himself, and was therefore exposed to infection from them, the cattle were probably infected around the time of their sale.

\section{Discussion}

An outbreak of $L$ hebdomadis was reported in $1969^{2}$ but until 1978 this serogroup has accounted for only a few leptospiral infections, six out of 42 in 1971, for example. ${ }^{3}$ Human infections with this serogroup are more likely when the local population of the natural reservoir hosts, voles and fieldmice, is high. Wet weather in summer, as was experienced in 1968 and in $1978,{ }^{2}$ encourages the spread of the organisms among these rodents. The farmer commented that he had a particular problem with mice on his farm.

A major outbreak of $L$ hebdomadis has produced mastitis in cattle in Thirsk, ${ }^{4}$ and this organism has been associated with mastitis in cattle in North Wales. Interestingly, the leucocyte count of the milk from the herd reported here rose to $10^{9} / 1$ from its usual level of $0 \cdot 16-0.35 \times 10^{9} / 1$ around the time of the first human illness.

The first outbreak of $L$ hebdomadis infection in Britain was reported in 1969.2 Four cowmen were affected by a febrile illness of whom two had a lymphocytic meningitis. The illness is self-limiting, but Sakula and Moore $^{2}$ were apparently successful in preventing clinical illness in one person by the use of penicillin. It was concluded that cattle were the direct source of human infection rather than rodents.
Christie $^{5}$ reports that $L$ canalicola causes many cases of lymphocytic meningitis attributed to viral infection. Since $20 \%$ of cattle in the UK have been shown to have antibodies to $L$ hebdomadis, ${ }^{6}$ this infection should be considered in people who have occupational exposure to cattle and bovine carcasses, and measures taken to minimise infection should include avoiding contamination of broken areas of skin and penicillin prophylaxis in key operators. Wet weather in summer seems to increase the incidence of this infection.

We acknowledge the help of the Leptospira Reference Laboratory, who performed the serological tests. Dr E G F Tinsley, consultant pathologist, gave valuable help, and Dr G B R Fisher, general practitioner, obtained blood samples from the farmworkers and identified those who had been ill.

\section{References}

${ }^{1}$ Coghlan JD. Leptospirosis in man, British Isles, 1978. $\mathrm{Br}$ Med J 1979;ii:872-3.

2 Sakula A, Moore W. Benign leptospirosis: first reported outbreak in British Isles due to strains belonging to the hebdomadis serogroup of Leptospira interrogans. $\mathrm{Br}$ Med J 1969;i:226-8.

${ }^{3}$ Leptospiral Reference Laboratory. Leptospirosis. Communicable diseases record 1975/25. Page 1 .

4 Veterinary Investigation Service. Leptospiral mastitis outbreak. Veterinary Record 1979;104:2.

${ }^{5}$ Christie AB. Infection diseases-epidemiology and clinica! practice. Edinburgh: Churchill Livingstone, 1974:907-33.

${ }^{6}$ Coghlan JD, Norval J. Animal leptospirosis in the British Isles. Veterinary Record 1967;80:659-60. 